DOI: $10.2478 /$ pof-2018-0006

VOLUME 10, ISSUE 1, 2018

ISSN: $2036-5438$

\title{
The role of the Capital Markets Union: towards regulatory harmonisation and supervisory convergence \\ by \\ Sérgio Coimbra Henriques*
}

Perspectives on Federalism, Vol. 10, issue 1, 2018 


\section{Abstract}

The Council is a crucial intergovernmental institution of the European Union. However, the complex, opaque and consensual character of the decision-making process in the Council puts its legitimacy into question. Intergovernmentalist theory posits that it is sufficiently legitimised, indirectly, by the member state governments. Constructivist research, on the other hand, suggests that socialisation might disturb the relaying of positions from the national to the supranational level, as the former approach implies.

This paper aims to explore these issues, in particular related to representation and consensus. It contains an analysis of material generated in in-depth interviews. The Capital Markets Union (CMU) initiative serves as an umbrella term for regulatory changes directed at the overall development of European capital markets. As such, when analysing the legal framework of the CMU, it is important to note that this involves an undertaking which goes beyond the regulation of financial systems, also aiming to achieve supervisory convergence throughout the member states of the European Union. Indeed, it is perhaps one of the clearest examples of federal implications within the EU. All the synchronous movements enacted into law, leading towards harmonisation and supervisory convergence, show us that the $\mathrm{CMU}$ is an foundational piece in a collective journey towards ever greater integration in terms of economic governance and economic policies. Nonetheless, even if the CMU is one of the few cross-country risk-sharing mechanisms available to the EU, its implementation faces difficulties (as well as the looming Brexit) that demand careful analysis.

Key-words

Capital Markets Union, economic federalism, risk sharing, supervisory convergence, free movement of capital 


\section{Capital Markets Union and the notion of a federal European Union}

The free movement of capital within the European Union, as prescribed by articles 63 to 66 of the Treaty on the Functioning of the European Union, is a broad endeavor; it can probably be best described as one, overarching, all-encompassing, provision. Even if there are doubts about the legal provisions of its breadth of application, everyone can agree on the tremendous difficulties in achieving the enforcement of this freedom beyond the mere principle. Crafting such a freedom demands types of legal harmonisation, translated into expectations, and requirements concerning all activities relevant to the movement of capital across all member-states. ${ }^{\mathrm{I}}$ More importantly, as an exhaustive principle, establishing the free movement of capital for citizens of the European Union demands, from every member-state, the type of union-wide imposed harmonisation that encroaches on their ability to regulate their own sphere of competences.

Within the organisation of constitutional powers amongst member-states, demanding a freedom of capital flows implies a high (the highest?) level of legal and political integration in economic and related policy areas. In short, a full liberalisation of capital movements within Member States, as introduced by the Maastricht Treaty, goes much further than the mere expectation that member-states simply remove restrictions to the extent necessary for the functioning of the common market. But this desired end goal has already involved, and will involve many more, intermediate steps.

As economic and political circumstances gradually changed, globally and in Europe, the stage became set, step by step, for the realisation of an Economic and Monetary Union (EMU). At this time, EMU exists in practice (as several steps have been taken towards more coordination of national economic and monetary policies), ${ }^{\text {II }}$ but only in part. Its full realisation is currently a matter of theory and legislative intent. In this movement towards free movement of capital, built upon the notion of free movement of goods and services, a common EU capital market, ${ }^{\mathrm{III} / \mathrm{IV}}$ is, both in name and in practice, a necessary element to achieve the concept of a European Single Market (of goods and services). ${ }^{\mathrm{V}}$

From a macro-economic point of view, monetary policies can aim for either an expansionary or contractionary focus. Different intentions underpin the decision to either increase or curtail the supply of money provided to the economy, which means that, across 
the EU, different economic zones present differing demands in terms of these policies, and, within the EMU, a balancing act is difficult to achieve. In fact, considering current circumstances, such as Euro related interest rates close to zero, and the impossibility of using expansive fiscal policies due to the frail economic situations of most member-states, little can be done in the field of monetary policies in order to appease to everyone involved. Instead, the focus must be placed on deepening structural reforms that overhaul the functioning of the market in order to make it more amenable to investors, and competitive in comparison to that offered by third party states. In this regard, the Capital Markets Union (CMU) can be understood as one of the possible answers to these limitations (Fernández 2016: 4-5).

The idea of the CMU immediately calls to mind another EU legislative project, now a reality, the European Banking Union. Launched in 2010, the initiative aimed to provide a three-pillar answer to systemic risk posed to banks within the European Union (especially due to the state debt they held). ${ }^{\mathrm{VI}}$ If we were to compare the Unions (European Banking and Capital Markets), it is possible to argue that the CMU will not involve a profound change to financial markets in the short-term. But, although there are no significant changes to the overall organisation and functioning of the system, its implications are more pervasive, and long-term focused.

Instead of trying to alter the relevant framework, the CMU entails considerable expectations of harmonisation, and more efficient rules being implemented, with the aim of establishing firm foundations for the development of EU capital markets and the diversification of the sources of financing available to EU companies. Still, the CMU's scope is larger as its provisions are applicable to all member-states, whereas the European Banking Union is only implemented in member-states that have the Euro as their currency. ${ }^{\text {VII }}$ Hence, we can conclude that the CMU boasts a distinct end from that of the European Banking Union. Where one aimed to centralise the banking policy framework, providing an adequate supervisory system (Véron 2014: 4-5), ${ }^{\mathrm{VIII}}$ the other seems not to be so intent on a movement towards centralisation, instead leaning towards a diverse set of objectives for development. ${ }^{\mathrm{IX}}$ This broader scope is also visible in the fact that there are no indications of a supervising body for CMU implementation being established. That decision seems to be rooted in the fact that, as we will see, the CMU implies a change in a 
heterogeneous group of subjects, with considerably different expectations of harmonisation in each one.

\subsection{Free movement of capital and capital market development}

Achieving the free movement of capital, and capital market development, does not represent a truly new objective for the EU. In fact, a common market for capital was one of the goals of the Treaty of Rome, where it was one of the tenets of ever advancing European integration. Yet, the crisis in 2008 brought a screeching halt to the process of development of European capital markets, as investors' confidence in capital markets in general plummeted. From 2008 to 2014, legislative changes in this regard were focused on attempts to re-establish confidence and trust in the European financial system. ${ }^{\mathrm{X}}$

While addressing the European Parliament during his nomination process in 2014, Commission President Jean-Claude Juncker announced one of the objectives of his tenure: to remove all the barriers and blockages that prevent cross-border investment within the European Union, aiming to ensure the goal of free movement of capital through several initiatives that would be put under the umbrella of a "Capital Markets Union". Progress on that front has been relatively swift, with the publication of a Green Paper on "Building a Capital Markets Union" in February of 2015, ${ }^{\mathrm{XI}}$ after which the Council adopted conclusions on this initiative, ${ }^{\mathrm{XII}}$ prompting the Commission to launch its Action Plan on September 30th 2015. ${ }^{\text {XIII }}$ The Commission's position, according to the Action Plan, was that a CMU would mobilise capital and channel it to companies and infrastructure projects, by allowing for different funding sources all across Europe. This would lead to increased cross-border risk-sharing and more liquid markets, which would deepen financial integration, lower costs and increase European competitiveness.

As investors' confidence and trust in capital markets was felt to have been reestablished at the time, the objective was now to increase capital markets' efficiency and its ability to provide financing to European companies. Since then, a more complete set of goals has been put in place to create deeper, more integrated capital markets across the EU, which, in turn, should lower costs for investors and enhance market resiliency.

A financial system is comprised of a set of institutions and markets that allow for certain contracts and services, that then make it possible for economic agents to desynchronise both their risks and the time when those risks manifest. Within a fully 
implemented CMU, cost of capital would tend to be equal throughout the EU, facilitating or promoting investment market value for all relevant dimensions of activity (investment funds, SME funding, long term investment - i.e. infrastructure projects - and many others), as member-state borders would become mostly irrelevant in terms of investors' choices. Capital could then flow between states with reduced intervention by financial intermediaries or service providers in general. In fact, amongst other aims, a CMU would empower investors to provide significant funds for investment across the Single Market without any barriers.

At the time the CMU was proposed (and, as it seems, at the time of writing), the financial system of EU member-states was thought to be overly reliant on bank financing for companies (Véron, Wolff 2016: 131-132). ${ }^{X I V}$ SMEs in particular have limited access to financial markets. Few companies are able to access venture capital or even take part in regulated capital markets. For example, share and bond issuance by SMEs is uncommon across the EU and, when it exists, the offer is mostly confined to the domestic market, as the issued securities are, predominantly, not freely offered across different member states mostly due to the differing rules and standards on their prospectuses, ${ }^{\mathrm{xv}}$ or the placement agent lacking authorisations to operate in different jurisdictions.

To this, one must add that there is hardly any appetite from investors to take the risk of acquiring capital or debt of companies (especially SMEs) located in different jurisdictions, where one simply has no assurance of access to reliable company information, necessary for the investor to base his decision, and where an investor would then have no clear way of knowing what would happen to his investment if something were to go wrong (in terms of establishing his claim in a different jurisdiction). ${ }^{\mathrm{XVI}}$

Conversely, and focusing our argument on the type of corporate entity that has the greatest difficulties to overcome in order to access capital markets, SMEs are mostly reliant on bank financing; a fact cannot be changed at whim or by legislative action. This means that their access to capital markets will always be limited by their (usually high) exposure to bank financing, and thus demands specific considerations.

Even if we were to discount the limiting effect on SMEs resulting from their dependency on bank financing, the EU has a very fragmented capital market infrastructure which must somehow be consolidated. In November 2016, there were, within the EU, over 100 regulated markets, about 150 multilateral trading facilities, 20 central 
counterparties, 42 central securities depositories and securities settlement systems and 6 trade depositories (Meijer 2016). To address this challenge, settlement (CSDR), ${ }^{\mathrm{XVII}}$ market infrastructure (EMIR) ${ }^{\mathrm{XVIII}}$ and cross-border settlement (T2S) ${ }^{\mathrm{XIX}}$ have all been subjected to harmonisation, which has made things simpler in the post-trade segment. ${ }^{\mathrm{xx}}$ Legislation was also put into place to provide a framework for investment intermediaries that provide services to clients for shares, bonds, units in collective investment schemes and derivatives, as well as the organised trading of financial instruments. ${ }^{\mathrm{XXI}}$

As noted, the EU legislative body has already taken action towards the enactment of a CMU. Such a broad scope of subjects organised under a simple acronym (the CMU) implies that judging the effects and results of these concerted actions will be hard. In fact, different indicators can be used to analyse the results of the implementation of the Capital Markets Union, and the Commission has proposed a substantial set of objectives of the CMU that we evaluate against certain indicators. ${ }^{\text {XII }}$

It must first be noted that, in general, capital markets in the European Union show an amount of capitalisation in percentage of GDP that is smaller than most comparable markets ${ }^{\text {XXIII }}$ (in part, explained by the overwhelming presence of bank financing), and that value is set to decrease with the upcoming Brexit. That being said, the Commission aims to meet the following general objectives with the CMU initiative:

- Financing for innovation, start-ups (high innovation companies) and non-listed companies: ${ }^{\text {XIV }}$ Towards this objective we find the revision of venture capital regimes, attempts to correct information asymmetries concerning companies' financial situation (which prevents investors from correctly gauging the risk involved in investment) and the regulation of new forms of financing for companies (i.e. crowdfunding);

- Making it easier for companies to raise funds on public capital markets: ${ }^{\mathrm{XxV}}$ Simplifying the prospectus regime, ${ }^{\mathrm{XxvI}}$ improving the market for bonds (mostly by promoting the liquidity of those markets), and examining the best way to provide SMEs with access to capital markets; ${ }^{\text {XVII }}$

- Promoting investment in long-term, sustainable projects and infrastructure projects: ${ }^{\mathrm{XVIII} / \mathrm{XXIX}}$ Fostering retail and institutional investment, mainly by revising capital demands for financial entities and insurance companies; 
- Leveraging banking capacity to support the wider economy, namely financial services and in the insurance sector: ${ }^{\mathrm{xx}}$ The first by supporting new FinTech developments and the second by evaluating possible changes in the insurance industry (namely, establishing European pensions schemes and revising limits in investment in risk capital or company issued debt for insurance companies), as well as trying to facilitate the cross-border commercialisation of investment funds. More importantly, the CMU will entail a new legal regime for titularisation, ${ }^{\mathrm{XXXI}}$ based on the tenets that form the STS acronym (simple, transparent and standard) in order to make it easier to communicate to investors the characteristics of certain products;

- Facilitating cross-border investing: ${ }^{\text {XxII }}$ Namely by harmonising relevant civil law and fiscal law provisions to promote, as much as possible, cross-border commercialisation of investment funds, as well as reducing (eliminating) crossborder fees. On this subject, relevant progress has been made, for example, in terms of promoting the harmonisation of insolvency law across the EU. XXXIII

While these objectives and indicators are interesting tools and relevant benchmarks, one must mention that they are not clear-cut, as European capital markets are subject to several other factors, the effects of which cannot be removed from these, or any other, indicators.

While economic activity demands, for example, the existence of commerce, capital markets are, in fact, not a necessary part of economic activity. Economies can make do with alternatives to provide funding; banks, for example, can act as intermediaries replacing the need for capital markets. Their concern, linking borrowers and lenders, makes capital markets competitive and impersonal (whereas banking might be based on mutual trust between the parties). Investment in capital markets occurs only when it is advantageous for investors. This means that fostering capital market development, while desirable, ${ }^{\text {xxIV }}$ must stem from agreeable market conditions and legislative initiatives, which ensure their attractiveness. Otherwise, they will be underdeveloped and not sufficiently liquid; prerequisites that, in turn, must be accompanied by a regulatory and supervisory framework under which financial stability risks are under control. 
In considering the importance of securities law in general as the plethora of legal rules that govern and conduct capital markets, for example outlining the requirements that must be met for firms to access investors and raise money, we must also consider that evolving technology has created new possibilities in the functioning of capital markets, namely generating global liquidity. If a certain jurisdiction imposes onerous regulatory costs on access to capital markets, firms might simply make investments available elsewhere and investors might simply choose to invest somewhere else. Due to this global liquidity, those decisions would mean, in themselves, that investment simply would not take place in the markets that are less attractive, ${ }^{\mathrm{xxx}}$ losing to others that are more appealing.

\subsection{Risk-sharing and the implementation of the Capital Markets Union}

The implementation of the CMU project is one of the clearest examples of federal implications within the framework constituted by the juridical entities of the European Union, with several elements, characteristic of federalism, being deeply ingrained in the framework. One of the greatest challenges in working towards a CMU is the regulatory aspect. There is a tremendous diversity of non-bank finance legislation across EU member states. As we know, EU law takes precedence over national legal orders and member-states' courts; administrative authorities must ensure that national law does not conflict with its provisions. ${ }^{\mathrm{xxyI}}$ This means that a top down approach, such as the one being implemented, is possible given existing Treaty provisions. Nonetheless, regulation of CMU requires justification on how it would benefit the Union as a whole.

Capital markets integration, or financial integration in general, has the relative advantage of supporting risk-sharing between strong and weak sections of the entity. In the case of the EU, this means that the risk-sharing (here in the sense of smoothing of consumption) $^{\text {XXXVII }}$ between countries counterbalances risks that are specific to each part of the whole. In other words, it increases the union's welfare by hedging state-specific risks within the totality of member-states. In the EMU and, in particular, in the euro area, a single monetary policy is unable to react to asymmetric shocks (problems arising in certain portions of the EU when other portions are having no difficulties due to disjointed business cycles). This means that risk-sharing is key in mitigating the effects of those shocks. If consumption can be, and is, positively influenced due to the existence of risksharing mechanisms (for example, robust market or fiscal mechanisms), the overall 
volatility of aggregate consumption is also reduced, providing the welfare gains as discussed. This applies not only to countries ultimately affected by shocks, but to all of the $\mathrm{EU}$, as any macroeconomic adjustments required to compensate for the effects of the shock are not as brutal.

When considering this mechanism of risk-sharing, the case of the EU is special. Labour mobility, for example, is possible, but made harder by the existence of different languages within the EU. A tax system at the supranational level is also unrealistic at this point of time, at least from a political point of view. Furthermore, limits on fiscal deficits ${ }^{\text {xxxvIII }}$ also limit member-state governments in their attempts to smooth large shocks. In fact, as Furceri and Zdzienicka (2013: 16-17), risk-sharing mechanisms in the euro area appear to have been particularly ineffective during financial crises and severe downturns, significantly less so than in other federations.

As Vitor Constâncio puts it:

"Ideally, the CMU should achieve the completion of the single market for capital within a common-currency union. This completion is vital to reap the full benefits of risk-sharing across borders and not be limited by border effects from past institutional legacies. Overcoming these border effects is to be achieved through regulatory and non-regulatory actions, including the harmonization of key legislation related to financial products. While the regulatory and non-regulatory actions will be instrumental in capturing market-provided risk-sharing, deeper capital markets have a particularly high potential to smooth risks across national borders (...) Broad objectives such as capital market development, deepening financial integration and achieving risk-sharing should be at par with specific proposals such as facilitating funding for corporates in general and for SMEs in particular. Key areas such as securitization, insolvency regimes, securities holders' rights and tax legislation need to be prioritized. All these are important to ensure equal treatment of users of capital markets across Member States, the very essence of a CMU" (Constâncio 2016).

As long as the principle of equal treatment of users across member-states is respected, a CMU aimed at developing European capital markets is one of the few cross-state risksharing mechanisms that can be used by the EU.

\subsection{A testing ground for supervisory convergence}

In the EU, supervision of banking, insurance and securities markets is characterised by a multi-layered system of authorities organised by both sectoral area and level (European or national) of supervision and regulation. This layered structure demands the existence of 
coordinating bodies and instruments as well as some form of coordination between all entities. Although several actors form the European System of Financial Supervision, we will focus on securities and markets supervision. ${ }^{\text {XxIx }}$ Such supervision is achieved through a complex, interconnected, system consisting of the European Securities and Markets Authority (ESMA), ${ }^{\mathrm{XL}}$ the joint Committee of the European Supervisory Authorities ${ }^{\mathrm{XLI}}$ and, finally, national supervisory authorities.

For the CMU specifically, at the EU level the European supervisory authority is ESMA, set up with the scope of covering securities markets and participants (exchanges, traders, funds, etc.). Despite that scope, ESMA is solely afforded responsibility for the registration and supervision of credit-rating agencies and trade repositories, as well as recognising third-country central counterparties. Here national administrative authorities are only represented within the European supervisory authority; they can provide input, and any form of necessary collaboration is made easier by this constant contact.

At the micro-prudential level (the supervision of individual institutions), day-to-day supervision is done at a national level by competent administrative authorities. At the macro-prudential level, ${ }^{\text {XLII }}$ we find the European Systemic Risk Board (ESRB), ${ }^{\text {XIIII }}$ which is directed at preventing systemic financial stability risk in the EU, taking note of all relevant macro-economic developments. Its main functions involve the collection and analysis of relevant information as well as identifying and prioritising risks, to issue warnings and recommendations and monitoring their follow-up (namely, confidential warnings directed to the Council when an emergency situation may arise). In practice, these functions are performed in an analogous fashion to those of the ECB, as the President of the ECB is also the Chair of the ESRB. ${ }^{\text {XLIV }}$

Overall, we find a layered structure that is strongly fragmented and, practice shows, was unable to provide a concrete and structured approach to financial crisis. We can once again draw comparisons with the European Banking Union. In this initiative, from 2012, integration and cooperation problems were addressed with the implementation of the Single Supervisory Mechanism, a Single Resolution Mechanism, and the European Deposit Insurance Scheme (at the time of writing, to be implemented), with the three structures enforcing a top-down implementation of a single supervisory handbook. In contrast to the European Banking Union's actions, the CMU does not involve the same level of regulatory integration for EU capital markets and, as such, no single supervisory mechanism is 
envisioned. Instead, the intention is that the relevant European Supervisory Authorities (ESMA and EIOPA) will be better funded to enhance their capacity to act, and the relevant extant administrative authorities (European and national) expected to work in tandem, with greater cooperation and convergence, to ensure that CMU provisions are properly enacted and applied by the agents of a united EU financial system, without significant differences between them.

As such, in what regards the CMU, we find a different approach. The CMU took on a bigger goal - in answering the financial crisis of 2008 and the challenges of the following years, and answered it with a structured overhaul of the financial regulatory framework, component by component. Going forward, after implementing new banking supervisory rules (including the resolution mechanism), the Commission has been pushing for the CMU. But tackling the bigger goal does not stop here: The Commission is currently preparing a review of the EU's macro prudential framework in order to promote financial stability (by tackling macro-prudential risk). ${ }^{\mathrm{XLV}}$

Concerning CMU implementation, the most important topic in this context is still supervisory convergence, in particular the question of whether or not the European Supervisory Authorities need to be reimagined. ${ }^{\text {XLVI }}$ The European Parliament has emphasised that both legal and supervisory frameworks will play a fundamental role in the $\mathrm{CMU}$, as only the supervising entities can assure that all reform is brought into the day to day activities of financial intermediaries and other economic agents. ${ }^{\text {XLVII }}$

In advancing supervisory convergence, ESMA published, on 31 May 2017, an Opinion with nine general principles to be followed by national authorities in the context of the authorisation and supervision of regulated entities, especially when part of the management functions is delegated or outsourced to a third country entity, ${ }^{\text {XLVIII }}$ namely taking into account the context of Brexit and the necessary relocation of entities. ESMA's objective is to ensure a harmonised approach by all national level supervisory authorities. Without entering into the day-to-day activities of those authorities in these matters, ESMA has set clear limits for the application of the relevant legal provisions. ${ }^{\mathrm{XIX}}$

Although a strong capital markets union project demands an active role from the authorities responsible for supervision, changes made to the powers and responsibilities of those authorities remain to be seen. As far as the implementation of the capital market union initiative is concerned, we note an intention to ensure that little to no idiosyncratic 
legal provisions are added by national entities during the transposition phase of directives (so-called gold plating). In fact, that might explain the preferred option of establishing most applicable new rules in the form of directly enforceable European regulations, to ensure EU-wide regulatory consistency. If EU securities regulations are to be enforced in similar fashion across the CMU, ESMA probably must be afforded greater regulatory responsibilities over national entities, namely with some enforcement powers.

In conclusion, by analysing the legal framework that attempts to bridge the CMU, one finds a scenario fraught with a sense of overarching control and centralisation that must be deemed characteristic of a federalist approach to regulation.

\section{What about Brexit?}

Despite the looming Brexit, it seemed clear that no other country could expect benefits from the CMU greater than those in store for the UK's financial industry; the UK hosts Europe's largest capital markets. ${ }^{\mathrm{L}}$ Assuming, as seems more and more probable at the time of writing, that the UK will be denied access to the European Single Market, British capital markets will not be part of the CMU. This means that the most established fund management location, the city of London, would be out of the equation, and different prime capital markets hubs have to be found (Stander 2016:5-7). ${ }^{\text {LI }}$

In the absence of the UK, already on a path to leaving the European Union, the remaining member states face a rather different cost-benefit allocation among them. As Philip Stander notes, on the one hand several financial centers could benefit from a relocation of UK-based firms and activities and, on the other, member states would have to compensate for the loss of market depth to cushion the economic consequences on capital market funding (Stander, 2016: 6-10). The consequences of Brexit on the CMU project are dependent on future political decisions, and hinge on whether (i) the EU decides to accelerate its efforts to implement the CMU to counter the absence of the UK, (ii) the EU feels that the project is not warranted as much attention due to the absence of the UK or, even, (iii) whether Brexit negotiations allow for a deal to be struck where the UK's financial industry retains the ability to obtain "passports" for their firms to perform financial services within the EU. All signs point, quite clearly, to the first hypothesis. ${ }^{\text {LII }}$ 
Taking into account the consultation on the CMU back in 2015, ${ }^{\text {LIII }}$ discussed above, the remaining member-states stance concerning the CMU can be categorised in three groups. Most supportive of the initiative were Ireland, the Netherlands, Sweden and Luxembourg (member-states with highly developed financial markets); several other member states recognised the promise of the initiative, namely in the way it could improve financing conditions for SMEs and other business in smaller member-states; and France and Germany seemed to present limitations to the initiative, questioning the desirability of adopting a model of financial intermediation that reduces, in part, the importance of banks. One can imagine how different this positioning might have been if the consultation had been made in the absence of the UK as a member-state. Without London, the role to be played by all member-states would have changed. Both groups, those who have particularly developed financial markets, and France and Germany, would have a far more important potential position to assume, namely in terms of providing financial services in the absence of UK based firms.

\section{The current implementation of the Capital Markets Union}

The CMU was originally based on an implementation framework spread over several years, and already in motion (2015-2019). By 2017, the Commission intended to have completed the first phase of CMU measures, namely STS securitisation, ${ }^{\text {LV/LV }}$ prospectus rules to facilitate access to capital markets, ${ }^{\mathrm{LVI}}$ and the overhaul of both the venture capital funds regulation and the social entrepreneurship funds regulation. Next in line would be the EU personal pension product, ${ }^{\mathrm{LVII}}$ increased availability of green funds (climate action), developing and supporting EU green bonds standards, supporting the development of FinTech firms through regulatory guidance and adequate treatment of policy implications of innovations, a market for covered bonds, removing barriers for cross-border investment, reducing barriers in the post-trading environment, increasing supervisory convergence through the actions of ESMA, ${ }^{\text {LVIII }}$ and more. In fact, all of these actions were mentioned in one communication from the Commission on the CMU, titled Capital Markets Union - Accelerating Reform. ${ }^{\text {LIX }}$

This illustrates how the CMU now stands for a large group of initiatives and regulatory changes, serving as an umbrella term for the overall development of European capital 
markets. As such, when analysing the overall framework of the CMU, it is important to note that this is a comprehensive initiative and only with the passage of time will the actual priorities become clear.

More recently, the Commission issued its Mid-Term Review of the Capital Markets Union Action Plan, ${ }^{\mathrm{LX}}$ where the main priorities are identified as being: Strengthening the effectiveness of supervision to accelerate market integration; enhancing the proportionality of rules to support initial public offerings and investment firms; harnessing the potential of FinTech; using capital markets to strengthen bank lending and stability; backing sustainable investment ${ }^{\mathrm{LXI}}$ and cross-border investment; as well as supporting the development of local capital market ecosystems. It is hard to imagine that a broader set of priorities could exist, all directed at enabling the development of new forms of funding and also facilitating the access to the market by SMEs in order to decrease the EU's economy reliance on bank lending.

\section{Closing remarks and challenges yet to be addressed}

The poor development of EU capital markets has determined that EU companies have a greater dependence on bank financing than would be ideal, ${ }^{\text {LII }}$ a problem which prompted, in part, the project of creating the CMU. This initiative is important and necessary, but for European companies to reap the benefits can only work if all elements of the equation are assessed.

Alongside a reimagined Economic and Monetary Union, all the synchronous movements enacted into law towards harmonisation and capital flows within EU capital markets show us that the CMU is an fundamental element in the movement towards ever greater integration in terms of economic governance and economic policies in general. However, this integration is not free from difficulties, not the least of them the challenges of coping with ever greater European legal requirements that in time will come to supersede almost all manifestations of regulation by member-states. This ongoing economic and financial integration could be limited by the protection of constitutional principles at a national level, ensuring that the federal construct does not become so overbearing that it turns pernicious in nature. 
The distinctive characteristics of each member-state suggest that the effects of the $\mathrm{CMU}$ on each part of the whole could be wildly different. One must not forget that markets are not a redistributive mechanism. Capital markets, from this point of view, reward the strong and penalise the weak. ${ }^{\text {LXIII }}$ This focus on the implementation of the CMU will surely bring about positive change and growth for EU capital markets. But its advantages must be accompanied by countervailing actions consistent with a federalist view of the European Union, namely in terms of economic policy, or funding, both directed towards supporting the member-states who might not reap the benefits of that activity (even if the investments return is made possible by economic activity within its borders). Only if the circle is closed in this manner, so to say, will the existence of the CMU be translated into a smoothing of the effects of risk-sharing inside the EU.

Even if, with Brexit, most member-states operate in comparable financial systems (bank based, instead of market based as seemed to be the case in the UK), several conceptual and practical hurdles must still be overcome to achieve a CMU, such as eliminating the high level of segmentation in market agents; consolidating the information on transactions - and offers - at an European level, as well as issuer information (namely the debt they hold and ensuring that accounting and auditing standards are comparable within the EU); a single tax regime for capital movements, both for borrowers and issuers; harmonising national level supervision practices; or preparing centralised infrastructures for disclosure of financial information, relevant facts for investors and also conflicts of interest that might exist.

Taking all this into consideration, if any doubts were to be had at this point, the prevalence of the CMU leaves no room for a notion other than that of a Federal European Union. Still, the path must be that of subsidiarity whenever possible, in assuring supervisory convergence and, step by step, making sure that the CMU builds enough improvement into the regulatory framework and its implementation by member states to, over time, fulfill the CMU's goal. Increasing capital markets' prevalence also means increasing the risk of those markets, a growth that must be met by adequate action by both regulators and supervising authorities.

Although it is clear that national level solutions cannot alone fulfill the aims of the CMU, ${ }^{\text {LXIV }}$ the solution must not be to adhere to the other extreme - a European level exclusive status quo in terms of both regulation and supervision. ${ }^{\text {LXV }}$ 
Nonetheless, Brexit brings the need to relocate the European Banking Authority and, with it, the temptation to prepare legislative reform that would involve a rearrangement of the three ESAs, placing all supervisory and regulatory powers at the EU level, hoping to overcome cross-border barriers by means of extensive harmonisation of rules and centralisation of supervision. Considering what has been written up to this point on the particularities of the CMU, this solution hardly seems a better option, and would undermine the steady progress of the initiative.

Looking at the current development of the CMU, the critique can be made that the initiative seems to be intent in creating the conditions for large financial institutions to further concentrate investment and expand their offer of products and services (Thomadakis 2017: 6). ${ }^{\text {LXVI }}$ Still, if the overall result of the initiative proves to be increased transparency in capital markets, increasing accessibility to those markets by businesses, increasing market liquidity and the promotion and implementation of FinTech developments, ${ }^{\mathrm{LXVII}}$ the CMU will have greatly contributed to achieving freedom of capital within the EU's single market. And that is, in itself, of immense value for the future development of the EU under the auspices of a federal economic arrangement. ${ }^{\text {LXVIII }}$

In closing, it must be mentioned that the Commission has already made staunch declarations on the need to accelerate the implementation of CMU, prioritising the harmonisation of insolvency law and supervisory matters. ${ }^{\text {LXIX }}$ In particular, in the light of Brexit, the CMU presents an opportunity to determine whether or not supervisory competences are, in their current state, what they need to be, while, simultaneously, ensuring the enactment of several harmonisation movements that will reduce barriers to free movement of capital. Nonetheless, the completion of the CMU by 2019 seems to be a considerable challenge to meet. Perhaps, acknowledging this, the Commission's intention is to put into place the building blocks of the CMU by that date. ${ }^{\mathrm{LXX}}$ In fact, regulatory reform is but one of the first steps in achieving the CMU, only time will bring about the financial circuits, market conventions and technical infrastructures that take advantage of this revamped legal framework towards more efficient union-wide capital markets.

\footnotetext{
* Lawyer, PhD candidate at Universidade Nova de Lisboa.

I Annex I of Council Directive 88/361/EEC of 24 June 1988 for the implementation of Article 67 of the Treaty provides us with the definitions encompassed within the expression "movements of capital". It can mean very different things, such as securities investment, financing, real estate investments or purchases.

II The Treaty prohibits any restriction on capital movements and payments, both between Member States and
} 
between Member States and third countries. The principle was directly effective, i.e. it required no further legislation at either EU or Member States' level.

III In general, a market can be defined as a mechanism through which buyers and sellers of a certain product meet to determine the price and quantity of that product (normally, by gauging offer and demand). In capital markets, lenders are met with borrowers (either by banks, dealers, money markets or investment funds). In this sense, lenders and borrowers, through their intermediaries, trade in risk and time.

IV Capital markets, in the context of the Capital Markets Union, should be understood as shorthand for a long list of market segments and specifically excludes bank lending.

$\mathrm{V}$ Free movement of capital is one of the freedoms the European Single Market presupposes. Considering capital markets in particular, one must mention the Financial Services Action Plan of 1999 [COM (99) 232], the dawn of the EMU - mostly implemented in the beginning of the century, the Report of the High-Level Group on Financial Supervision in the EU Chaired by Jacques de Larosiere in 2009 and the creation of the European Supervisory Authorities in 2011.

VI Several works treat these matters in a comprehensive manner. In short, we are referring to firstly, the Single Rule Book, which established full harmonisation of banking regulation for banks operating within the European Union and the concentration of supervision powers in the European Central Bank, with mere participation of the national supervisors (in a manner comparable to the European System of Central Banks for the execution of monetary policies). Second, the creation of the Single Resolution Mechanism, separated from other supervising entities, in order to avoid possible conflicts of interest (see Regulation (EU) No 806/2014 of the European Parliament and of the Council of 15 July 2014 establishing uniform rules and a uniform procedure for the resolution of credit institutions and certain investment firms in the framework of a Single Resolution Mechanism and a Single Resolution Fund and amending Regulation (EU) No 1093/2010). Third, a European deposit guarantee scheme would constitute a third pillar of the European Banking Union. The Commission presented a legislative proposal and the European Parliament has been working internally on the steps to its realisation (see COM (2015) 586, which intends to amend Regulation (EU) 806/2014, and the Working Document by the Committee on Economic and Monetary Affairs on the European Deposit Scheme dated of 16.6.2016).

VII A remark that becomes less impressive when we consider the forthcoming Brexit.

VIII Which, before the implementation of the European Banking Union, was fragmented at the national level. It can be argued that said fragmentation proved dysfunctional at a federal level, because the incentives of individual national supervisors to be driven by banking nationalism collided with their prudential mandate.

IX All signs point towards the CMU's focus being not the financial sector but instead the development of the European economy in general.

x For example, establishing a framework for alternative investment fund managers (Directive 2011/61/EU of the European Parliament and of the Council of 8 June 2011 on Alternative Investment Fund Managers and amending Directives 2003/41/EC and 2009/65/EC and Regulations (EC) No 1060/2009 and (EU) No $1095 / 2010)$, in an attempt to limit wrongdoing, as well as efforts to improve market infrastructure resiliency which will be mentioned later on.

XI COM (2015) 63. This paper attempted to diagnose the current situation of EU capital markets through consultation of private and public agents. Over 400 contributions were received in a public consultation that was closed in May 2015. See also COM (2015) 630.

XII 9852/15 (Council conclusions on a Capital Markets Union - 16 June 2015).

XIII COM (2015) 468.

XIV Although this dependence on banks, coupled with the lack of alternative financing channels, is now signaled as one of the significant features of the European crisis and the lack of diversity in the financial system one of the obstacles to its resolution, this prevalence was once seen by policymakers as a factor of stability.

XV Where given the option, Member-states have implemented in different ways Directive 2003/71/EC of the European Parliament and of the Council of 4 November 2003 on the prospectus to be published when securities are offered to the public or admitted to trading. The EU Prospectus Directive will be repealed in 21 July 2019 by Regulation (EU) 2017/1129 of the European Parliament and of the Council of 14 June 2017.

XVI The so-called "home bias", caused by differences in language, regulatory and legal practice, tax and infrastructure. See ANDERSON et al (2015: 5).

XVII Regulation (EU) No 909/2014 of the European Parliament and of the Council of 23 July 2014 on improving securities settlement in the European Union and on central securities depositories and amending 
Directives 98/26/EC and 2014/65/EU and Regulation (EU) No 236/2012 (CSDR) was published in the Official Journal on 28 August 2014, and entered into force on 17 September 2014

XVIII Regulation (EU) No 648/2012 of the European Parliament and of the Council of 4 July 2012 on OTC derivatives, central counterparties and trade repositories

XIX Among participant Central securities depositories, TARGET2-Securities (T2S), is an European platform for securities settlement in central bank money, effectively eliminating the need for cross-border settlement. Migrations to the system are being done by waves and according to schedule.

$\mathrm{xx}$ Clearing, settlement, custody.

XxI Usually known as MiFID II, the second instance of the Markets in Financial Instruments Directive is the EU legislation that regulates firms who provide services to clients linked to 'financial instruments' (shares, bonds, units in collective investment schemes and derivatives), and the venues where those instruments are traded (Directive 2014/65/EU of the European Parliament and of the Council of 15 May 2014 on markets in financial instruments and amending Directive 2002/92/EC and Directive 2011/61/EU). changes are currently set to take effect from 3 January 2018 and also include extensive regulation (which, as a whole, is denominated the Markets in Financial Instruments Regulation - MiFIR).

XXII As per the Action plan on Building a Capital Markets Union. The analysis of the state of implementation of those measures (using the indicators mentioned in the following notes) can be found on the European Financial Stability and Integration review (European Commission, Banking and Finance, April 2016), available at: https://ec.europa.eu/info/system/files/efsir-2016-25042016_en.pdf.

xxIII Namely, the USA, Japan, China and Switzerland.

xxIV Indicators: Volume of crowdfunding, business angel investment, venture capital investment, private equity (assets under management).

$\mathrm{XxV}$ Indicators: Bank loans as a \% of total liabilities of Non-Financial Companies (NFC), Bonds as a \% of total liabilities of NFCs, NFCs' bonds (outstanding volumes), Number of bond issuances by NFCs, NFCs' stocks (outstanding value), Approved prospectus, SME Growth Markets, Companies listed on SME Growth Markets.

XXVI Proposing a material change in the way that information is addressed within a prospectus, centering it on the existence of specific risks relevant to the investor. In fact, Regulation (EU) 2017/1129 of the European Parliament and of the Council of 14 June 2017 establishes that the prospectus must only mention specific and material risk factors, makes it easier to incorporate information by reference (if it is already published elsewhere) and a shorter ("user-friendly") prospectus summary. Alongside a fast-track approval mechanism (Universal Registration Document), the Regulation demands the creation of a central prospectus database, where all prospectuses will be available for free. See also note xv. Many of these changes are directed at establishing easy disclosure rules so that more SME entities begin issuing financial instruments as a manner of financing.

XXVII Either by facilitating their access to public regulated markets or by instituting strong multilateral negotiation systems.

xxVIII Retail investment indicators: Infrastructure deals completed (global value), European project bond issuance, European project loan issuance, PPP transactions, Number of projects supported by EFSI, EIB financing for EFSI-supported projects, Expected total investment in EFSI-supported projects, ELTIFs, ELTIFs, Green bonds issuance (global value);

Institutional investment indicators: Households financial assets, EUR (\% of GDP), Share of financial assets other than currency and deposits, EUR (\% of GDP), Total assets of investment funds by investment policy (bonds, equity, mixed, MMFs, real estate, hedge funds), EUR (\% of GDP), Total assets of insurance corporations and pension funds by investment policy, EUR ( $\%$ of GDP).

XXIX The revision of the Solvency II regime as well as the revision of Capital Requirements Regulation were enacted as a way to fulfill this objective.

xxx Indicators: Volume of securitisation outstanding, Volume of securitisation gross annual issuance, Outstanding volume of covered bonds.

xxxi COM/2015/0472 final - 2015/0226 (COD).

XXXII Indicators: Efficiency of insolvency frameworks in EU Member States, Annual cost of burdensome withholding tax procedures, Capital mobility coefficient, Indicator of consumption risk sharing.

xxxiI Towards harmonisation of insolvency law, see Proposal for a Directive of the European Parliament and of the Council on preventive restructuring frameworks, second chance and measures to increase the efficiency of restructuring, insolvency and discharge procedures and amending Directive 2012/30/EU, 
published on 22nd November 2016. Regulation (EU) 2015/848 of the European Parliament and of the Council of 20 May 2015 on insolvency proceedings (recast) establishes rules when cross-border insolvencies take place.

xxxiv The development of capital markets, translated into a better matching of lenders and borrowers could lead to increased efficiency in fund allocation which would, in turn, support economic growth.

xxxv A relevant comparison can be made with corporate law. Non-competitive or too costly provisions concerning company law make investment in certain jurisdictions harder or less appealing for companies. But forming a company or some sort of subsidiary is an advantageous step to access that market as an economic agent that is given certain characteristics (mostly, limited liability). Differently, in capital markets, investors are particularly concerned with returns on investment in absolute terms and the associated risk, not so much with where that capital is applied and how the return on investment was achieved. This argument is further developed by Brummer 2008: 1111-1114.

Xxxvi In fact, no national law can be used to judge the validity of EU law, as the European Court of Justice is the only competent authority to do so.

XXXVII Economic theory postulates that, in a perfectly integrated world, full risk-sharing can be achieved where consumption in regions or countries grows at a constant pace and is insensitive to local fluctuations in income and wealth.

xxxvIII Stability and Growth Pact.

xxxIx This focus in capital markets doesn't intend to discount the fact that the insurance sector and pensions are, also and in certain conditions, forms of investment, which are the object of certain parts of the CMU legal reforms.

XL Regulation (EU) No 1095/2010.

XLI The European Supervisory Authorities are the European Central Bank (ECB), ESMA and the European Insurance and Occupational Pensions Authority (EIOPA).

XLII One must mention the existence of a Joint Committee of the European Supervisory Authorities, responsible for overall and cross-sectoral coordination. This includes: financial conglomerates; accounting and auditing; micro-prudential analyses of cross-sectoral developments, risks and vulnerabilities for financial stability, retail investment products; measures to combat money laundering; information exchange between ESRB and ESAs; and the development of relations between these institutions.

XLIII Regulation (EU) No 1092/2010 on European Union macro-prudential oversight of the financial system and establishing a European Systemic Risk Board and Council Regulation (EU) No 1096/2010 conferring specific tasks upon the European Central Bank concerning the functioning of the European Systemic Risk Board.

XLIV Moreover, the ECB provides the secretariat for the ESRB.

XLV On 7 November 2016, the Commission held a Public hearing on the Review of the EU's macroprudential framework which concluded a call for evidence period from 1 August until 24 October 2016, the intention is to enhance monitoring of risks arising from market-based finance.

XLVI On 21 March 2017, the Commission launched a public consultation on the operations of the European Supervisory Authorities.

XLVII Resolution 2015/2634, 9 July 2015

XLVIII ESMA, General principles to support supervisory convergence in the context of the United Kingdom withdrawing from the European Union (ESMA42-110-433).

XLIX ESMA also intends, in due time, to establish the Supervisory Coordination Network, which would allow national authorities discuss issues in relation to the relocation of UK market participants, in order to promote consistent decisions between different national authorities. Further measures to support supervisory convergence are being taken by ESMA, namely publishing, on 13 July 2017 three sector-specific opinions (one opinion on the asset management sector, one on investment firms and one on secondary markets.

L According to Wright 2016: 7, Brexit would reduce European capital markets depth by about 16\%.

LI Stander points out quite clearly the dominance of UK based services in EU capital markets, for example, UK venture capital markets account for $36 \%$ of total EU activity, UK trading platforms execute $40 \%$ of EU trades and UK based firms clear about $70 \%$ of euro-denominated trades. The UK only holds a smaller market cap in debt securities, and still stands at $11 \%$ of EU capital markets.

LII The Commission establishes that " $[\mathrm{t}]$ he departure of the United Kingdom from the Single Market reinforces the urgent need to further strengthen and integrate the EU capital market framework. . . it also strengthens the need for further integration of supervision at EU level' (in COM (2017) 292, 8) See $₫ 3$. 


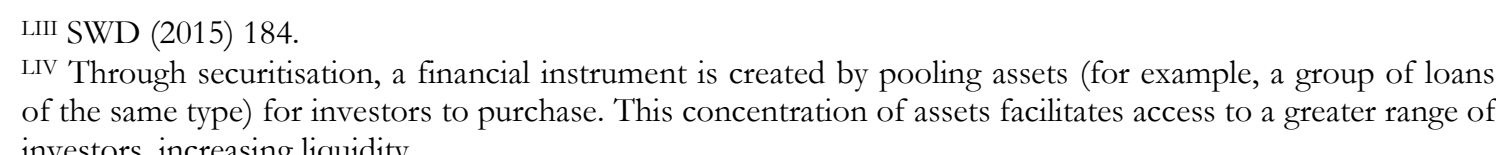
investors, increasing liquidity.

LV See COM/2015/0472 final - 2015/0226 (COD).

LVI See COM (2015) 583.

LVII Currently undergoing, Consultation on Capital Markets Union: Action on a potential EU personal pension framework (27.7.2017).

LVIII ESMA/2016/203, 11.02.2016.

LIX COM (2016) 601.

LX COM (2017) 292.

LXI As established by the UN 2030 Agenda for Sustainable Development (UN Resolution A/RES/70/1).

LXII In fact, this dependence caused the impact of the 2008 crisis to be enormous on EU's real economy, even larger than it was in the USA.

LXIII In general, markets can supplement federalism. Their competitive nature, as well as the intent to bear risk generated by activity in them, means that projects which are questionable from a return on investment point of view are generally not accepted for investment (as investors will not be interested investing in such projects). Still, active markets, by increasing the amount of capital available for development, pave the way for an eased burden in terms of federal intervention. Federal power can concentrate in key investments or infrastructure development that might not be considered by the investors in capital markets but are deemed necessary or important in the long term by citizens (this idea is further developed by Hildreth 2005: 41-44).

LXIV In fact, one could argue that supervisory convergence greatly reduces the risk of regulatory arbitrage between different member-states of the EU by investors.

LXV Hence, each problem to be tackled to the CMU must be met by different types of solutions. As Véron and Wolff put it, "[t] $\mathrm{bis}$ is best determined on a case-by-case basis. Both the present and the future situations are and will be bybrids between two extremes, in which supervision is, respectively, all-national (an unnecessary step backwards from the status quo) or all-European (an unrealistic and unnecessary prospect that would sit oddly with the subsidiarity principle)" (Véron and Wolff 2016:150), and, because of that need for different types of solutions, some changes to the organisation of the supervisory scheme might be justified.

LXVI Moreover, the initiative is also contributing to displace other heavyweight financial interests, as banks are naturally averse to the prospect of legislative and political action aimed at developing alternative financing channels (increasing competition).

LXVII In fact, the financial markets have yet to feel the incoming impact that technological disruptions (caused by technological advances in fields such as big data and artificial intelligence, among others) will surely inflict.

LXVIII Perhaps necessary to face other economic behemoths in equal terms, attempting to ensure growth and welfare for all Europeans.

LXIX "The perspective of the largest EU capital market actually leaving the EU makes this work even more urgent", Valdis Dombrovskis speaking to the Financial Times (14 September 2016). This was also the case with Jean Claude Juncker's speech on the subject (21 September 2016). See JUNCKER 2016.

LXX COM (2017) 292: 18. [ During the final revision of this text, the European Commission has issued, on 12 March 2018, COM (2018) 114, committing to put in place all of the building blocks of the Capital Markets Union by mid-2019, following the publication of, among others, $\operatorname{COM}(2018) 97$ and $\operatorname{COM}(2018) 109$. ]

\section{References}

- Anderson Niki, Brooke Martin, Hume Michael and Kürtösiová Miriam, 2015, 'A European Capital Markets Union: implications for growth and stability', Financial Stability Paper, XXXIII, Bank of England: 124.

- $\quad$ Brummer Chris, 2008, 'Corporate Law Preemption in age of global capital markets', Southern California Law Review, LXXXI: 1067-1114

- Constâncio Vítor, 2016, 'Risk Sharing and Macroprudential Policy in an Ambitious Capital Markets Union', Speech by the Vice-President of the ECB, available at https://www.ecb.europa.eu/press/key/date/2016/html/sp160425 1.en.html. 
- Fernández Soledad Rodríguez, 2016, 'La unión del mercado de capitales', Revista Iberoamericana de Mercados de V alores, Instituto Iberoamericano de Mercados de Valores, XLVIII: 2-8.

- $\quad$ Furceri Davide and Zdzienicka Aleksandra, 2013, 'The euro area crisis: need for a supranational fiscal risk sharing mechanism?', IMF Working Paper, 13/198: 1-33.

- Hildreth W. Bartley, 2005, 'Federalism and capital markets in Canada and the US: Financing infrastructure in the wake of hurricane Katrina', Policy Options: 39-45

- Juncker Jean-Claude, 2016, 'Complementary Mission Letter to Vladis Dombrovskis Comissioner for Financial Stability, Financial Services and Capital Markets Union', Brussels, available at https://ec.europa.eu/commission/sites/cwt/files/commissioner mission letters/dombrovksiscomplementary-mission en.pdf.

- Meijer Carlo R. W. De, 2016, 'Could blockchain bring the EU Capital Market Union forward?' available at https://www.finextra.com/blogposting/13334/.

- $\quad$ Stander Philip, 2016, 'What will happen with the capital markets union after Brexit?', Policy Paper 181, Jacques Delors Institut, Berlin: 1-16.

- Thomadakis Apostolos, 2017, 'How close are we to a Capital Markets Union?', ECMI Commentary, 44/17: 1-7.

- Véron Nicolas and Wolff Guntram B., 2016, ‘Capital Markets Union: A Vision for the Long Term', Journal of Financial Regulation, II (1): 130-153.

- Véron Nicolas, 2014, 'Defining Europe's capital markets union', Bruegel Policy Contribution, 2014/12: 1-

6.

- $\quad$ Wright W., 2016, 'Beyond Brexit: What next for European Capital Markets?’, New Financial: 1-9.

European Union Official Documents

- $\quad$ European Commission, 1999, Communication from the Commission - Implementing the framework for financial markets: action plan, COM (99) 0232.

- $\quad$ European Commission, 2015a, Commission Staff Working Document, Feedback Statement on the Green Paper 'Building a Capital Markets Union' - Accompanying the document Communication from the Commission to the European Parliament, the Council, the European Economic and Social Committee and the Committee of the Regions Action Plan on Building a Capital Markets Union, SWD (2015) 184.

- European Commission, 2015b, Communication from the Commission to the Institutions - Action Plan on Building a Capital Markets Union, COM (2015) 468.

- $\quad$ European Commission, 2015c, Green Paper on retail financial services: Better products, more choice, and greater opportunities for consumers and businesses, COM (2015) 630.

- $\quad$ European Commission, 2015d, Green Paper: Building a Capital Markets Union, COM (2015) 63.

- $\quad$ European Commission, 2015e, Proposal for a Regulation of the European Parliament and of the Council on the prospectus to be published when securities are offered to the public or admitted to trading, COM (2015) 583.

- European Commission, 2015f, Proposal for a Regulation of the European Parliament and of the Council amending Regulation (EU) 806/2014 in order to establish a European Deposit Insurance Scheme, COM (2015) 586.

- European Commission, 2016a, Communication from the Commission - Capital Markets Union - Accelerating Reform, COM (2016) 601.

- $\quad$ European Commission, 2016b, Proposal for a Regulation of the European Parliament and of the Council laying down common rules on securitization and creating a European framework for simple, transparent and standardized securitization and amending Directives 2009/65/EC, 2009/138/EC, 2011/61/EU and Regulations (EC) No 1060/2009 and (EU) No 648/2012, COM/2015/0472 final - 2015/0226 (COD).

- European Commission, 2017, Communication from the Commission to the European Parliament, the Council, the European Economic and Social Committee and the Committee of the Regions on the Mid-Term Review of the Capital Markets Union Action Plan, COM (2017) 292.

- European Commission, 2018a, Communication from the Commission - Action Plan: Financing Sustainable Growth, COM (2018) 97.

- $\quad$ European Commission, 2018b, Communication from the Commission - FinTech Action Plan: For a more competitive and innovative European financial sector, COM (2018) 109. 
- $\quad$ European Commission, 2018c, Communication from the Commission - Completing the Capital Markets Union by 2019 - time to accelerate delivery, COM (2018) 114.

- $\quad$ European Council, 2015, Council conclusions on a Capital Markets Union, 9852/15.

- European Parliament, 2015, European Parliament resolution of 9 July 2015 on Building a Capital Markets Union, Resolution 2015/2634.

- $\quad$ European Parliament, 2016, Working Document on European Deposit Insurance Scheme (EDIS), Rapporteur: Esther de Lange, DT $\backslash 1098209 \mathrm{EN}$.

Committee on Economic and Monetary Affairs

- $\quad$ European Securities and Markets Authority, 2017, General principles to support supervisory convergence in the context of the United Kingdom withdrawing from the European Union, ESMA42-110-433.

- European Securities and Markets Authority, 2016, Supervisory Convergence - Work Programme 2016, ESMA/2016/203. 